\title{
Rapid Papers
}

(Pages 191-216) 


\title{
Age-Related Changes in Protein Turnover and Ribonucleic Acid of the Diaphragm Muscle of Normal and Dystrophic Hamsters
}

\author{
By DAVID F. GOLDSPINK \\ Department of Physiology, Medical Biology Centre, Queen's University of Belfast, \\ 97 Lisburn Road, Belfast BT9 7BL, N. Ireland, U.K. \\ and GEOFFREY GOLDSPINK \\ Department of Zoology, University of Hull, Hull HU6 7RX, U.K.
}

(Received 1 October 1976)

\begin{abstract}
Diaphragm muscles of dystrophic hamsters were found to be larger than those of control animals at two of three ages studied. The additional growth of these afflicted muscles correlated with large increases in protein synthesis and concentrations of RNA. Protein breakdown was also increased in the dystrophic muscles, but to a smaller extent than synthesis.
\end{abstract}

Attempts to elucidate the underlying lesion(s) responsible for muscular dystrophy have prompted the study of nutritionally induced myopathies and several genetically dystrophic animals. Although there is little reason to believe that these animal myopathies are identical with the human forms of dystropy, it seems probable that our comprehension of the human disorders will be advanced by acquiring an understanding of the derangements of the animal myopathies. Many structural, physiological and biochemical changes have been reported for muscles from the dystrophic mouse (Coleman \& Ashworth, 1959; Srivastava, 1967, 1968; Goldspink \& Rowe, 1968), chicken (Julian \& Asmundson, 1963; Weinstock \& Iodice, 1969), human (Walton, 1963; Pennington, 1965) and vitamin E-deficient rabbit (Polishchuk, 1969). However, it is difficult to determine which of these various changes are an integral part of the lesion(s) and which are purely secondary changes associated with the general degeneration of the muscle. The myopathy of the dystrophic hamster appears to be slower in onset and generally less severe than in many other species (Homburger et al., 1966). Therefore an age-related study of the dystrophic process in this animal may enable greater dissociation of primary and secondary changes.

Dystrophy is usually specific to muscle (Simon $e t$ al., 1962; Goldspink, 1976b) and is expressed as a progressive wasting of the musculature with corresponding losses of intracellular protein (Simon et al., 1962; Srivastava, 1967, 1968). However, unlike denervation atrophy, where the net loss of protein occurs through an increase in protein breakdown and a complementary decrease in protein synthesis (Goldspink, 1976a), in dystrophy a higher turnover rate is established with the increase in breakdown exceeding the increase in synthesis (Simon et al.,
1962). The present study was undertaken to establish whether changes in protein synthesis or protein breakdown, or both, could be found in skeletal muscles of the dystrophic hamster, and to pinpoint more precisely the time of onset of such changes after birth.

\section{Experimental}

All experiments involved the use of normal (albino, AC strain) and dystrophic (B10 14.6, type A) male hamsters obtained from the Coombe Hurst Breeding Establishment (Gaughurst, Hants., U.K.). At three different ages after birth (i.e. $30 \pm 1,100 \pm 4$ and $230 \pm 12$ days) animals were killed by cervical dislocation, and the appropriate muscles were rapidly removed and immersed in Krebs-Ringer bicarbonate buffer (Deluca \& Cohen, 1964). Hemidiaphragms were dissected free of the ribs, gently blotted to remove excess of buffer and weighed on a torsion balance. Average rates of protein syntheis and protein degradation were measured in these isolated muscles by the method of Fulks et al. (1975). That is, protein synthesis was measured as the incorporation of tyrosine into muscle proteins after a $2 \mathrm{~h}$ incubation in a suitable medium with nutrients, $0.02 \mu \mathrm{Ci}$ of L-[U- $\left.{ }^{14} \mathrm{C}\right]$ tyrosine $(483 \mathrm{mCi} / \mathrm{mmol}$; The Radiochemical Centre, Amersham, Bucks., U.K.)/ml and L-tyrosine hydrochloride ( $0.1 \mathrm{mM})$. Actual calculation of the tyrosine incorporated was made by dividing the incorporated $\left[{ }^{14} \mathrm{C}\right]$ tyrosine radioactivity by the specific radioactivity of the intracellular tyrosine pool. In this manner possible changes in specific radioactivity of the intracellular tyrosine pool with respect to synthesis are allowed for. Protein breakdown was determined independently of synthesis by measuring the release of tyrosine into intracellular 
amino acid pools and into the surrounding medium after a $2 \mathrm{~h}$ incubation. Muscle protein was measured by the method of Lowry et al. (1951), with bovine serum albumin [Sigma (London) Chemical Co., Kingston-upon-Thames, Surrey, U.K.] as a standard.

\section{Results and Discussion}

The diaphragm muscle of normal and dystrophic hamsters was studied at three different ages. The whole body and hemidiaphragm weights of the normal animals increased in a roughly linear manner with increasing age (Table 1). Although this was true of the body weights of the dystrophic hamsters also, growth of the diaphragm markedly outstripped that of the normal muscle between 30 and 230 days (Table 1). The total protein content of the dystrophic diaphragm was significantly higher than that of the control muscles at $\mathbf{1 0 0}$ and 230 days of age, but this was only by virtue of the larger muscle sizes in the dystrophic animals. When protein was expressed per unit wet wt. these differences disappeared, since the protein composition of the control and dystrophic diaphragms was $18 \pm 0.5 \%$ and $17 \pm 0.7 \%$ respectively. These simple observations on muscle size and protein contrast sharply with the muscle wasting and protein losses found in association with dystrophy in most other species.

Since the amount of tissue protein depends on the balance between rates of synthesis and degradation, both regulatory processes were measured in an attempt to explain the additional growth of the diaphragm of the afflicted animals. The turnover of muscle proteins of the normal hamster appears to become slower with increasing age (Table 2). Similar results have been found in the mouse (Srivastava, 1968; D. Goldspink, unpublished work). Although the turnover rates were essentially the same in the diaphragms of the two groups of animals at $\mathbf{3 0}$ days, both synthesis and breakdown were higher in the dystrophic tissues compared with controls at later ages (Table 2). These increases were not due solely to the increased muscle mass, since the changes were evident when expressed per $\mathrm{g}$ of tissue as well as per whole muscle (Table 2). The larger percentage increase in synthesis than in breakdown (Table 2) presumably explains the accelerated growth of the dystrophic diaphragm after 30 days.

Although the dystrophy of other species is known to alter the rate of uptake of certain amino acids by muscle (Diehl \& Jones, 1966), we found no evidence to suggest that the transport of tyrosine was affected at any stage of the dystrophic process. Similarly, the size and specific radioactivity of the intracellular tyrosine pools expressed per $\mathrm{g}$ of muscle were the same for the tissues from the control and dystrophic animals.

Attempts were then made to relate the concentrations of RNA to the rates of protein synthesis in the normal and afflicted diaphragm muscles. As previously reported (Millward et al., 1973; Goldspink, 1976a), changes in the concentrations of RNA probably reflect changes in the ribosomal capacity to participate in protein synthesis, and changes in protein synthesis per unit of RNA reflect the active involvement of ribosomes in translation. Although the total RNA content of the diaphragm of the normal hamsters increased slightly with increasing age and muscle size, the accumulation of RNA proceeded more slowly than the general gain in muscle mass, since RNA per $g$ of muscle decreased with age (Table 1). At the three ages studied, RNA concentrations were significantly higher in the dystrophic muscles compared with controls, suggesting

Table 1. Measurements of wet weight and RNA concentrations of diaphragm muscles from normal and dystrophic hamsters as a function of age

Each value is the mean \pm S.E.M. of determinations made on at least six normal and six dystrophic hamsters. Statistical significances $\left({ }^{*} P<0.005\right)$ of the differences between the two means were determined by Student's $t$ test. The extraction (Goldspink \& Goldberg, 1973) and assay (Manchester \& Harris, 1968) procedures for RNA have been described elsewhere.

Animal
age
(days)

30

100

230
Control Dystrophic $\%$ increase Control Dystrophic $\%$ increase Control Dystrophic $\%$ increase
Body wt.

(g)

$44 \pm 1.7$

$39 \pm 1.9$ $-11$

$91 \pm 4.9$

$108 \pm 3.9$

19

$127 \pm 11$

$123 \pm 4.0$

$-3$
Hemidiaphragm

wet wt.

(mg)

$45 \pm 1.6$

$42 \pm 1.7$

$-6$

$88 \pm 2.6$

$148 \pm 4.4$

$68 *$

$113 \pm 6.1$

$194 \pm 5.1$

$72 *$
RNA content

$\begin{array}{cc}\begin{array}{c}\mu \text { g of RNA P/ } \\ \text { hemidiaphragm) }\end{array} & \begin{array}{c}\text { ( } \mu \text { g of RNA P/g } \\ \text { of diaphragm) }\end{array} \\ 5.8 \pm 0.3 & 130 \pm 6.1 \\ 6.8 \pm 0.3 & 161 \pm 5.3 \\ 17^{*} & 24^{*} \\ 8.1 \pm 0.3 & 97 \pm 2.0 \\ 25 \pm 1.5 & 173 \pm 10 \\ 206^{*} & 78^{*} \\ 8.1 \pm 0.3 & 81 \pm 4.3 \\ 20 \pm 1.0 & 117 \pm 6.2 \\ 144^{*} & 44^{*}\end{array}$


Table 2. Average rates of protein synthesis and protein breakdown of diaphragm muscles from normal and dystrophic hamsters as a function of age

Average rates of protein synthesis and breakdown were measured in isolated hemidiaphragms. Synthesis was measured as the incorporation of tyrosine from the medium into muscle proteins after a $2 \mathrm{~h}$ incubation. Breakdown was measured as the combined release of tyrosine into intracellular amino acid pools and into the surrounding medium after a $2 \mathrm{~h}$ incubation. For reasons described elsewhere (Goldspink, 1976a), these muscles exhibit a negative nitrogen balance when incubated in vitro, i.e. breakdown exceeds synthesis. RNA P was determined in the same hemidiaphragms used for measuring protein synthesis. Each value is the mean \pm S.E.M. of determinations made on diaphragm muscles from a minimum of six normal and six dystrophic hamsters. Statistical significances $\left({ }^{*} P<0.01\right)$ were determined by Student's $t$ test.

Protein synthesis (nmol of tyrosine incorporated/2h)

\section{Animal age (days)}

30

100

230 Dystrophic (per hemidiaphragm)

$11 \pm 0.7$

$11 \pm 1.8$ $-3$

$4.3 \pm 0.2$

$21 \pm 0.8$

$2.2 \pm 0.3$

$9.1 \pm 0.8$

$314^{*}$
Control $\%$ increase

Control Dystrophic $\%$ increase Control Dystrophic $\%$ increase
Protein breakdown

(nmol of tyrosine released/2h)

$\begin{array}{cc}\begin{array}{c}\text { (per } \\ \text { hemidiaphragm) }\end{array} & \begin{array}{c}\text { (per g of } \\ \text { diaphragm) }\end{array} \\ 29 \pm 0.9 & 665 \pm 25 \\ 28 \pm 1.4 & 731 \pm 33 \\ 2 & 10 \\ 22 \pm 0.9 & 247 \pm 9 \\ 51 \pm 2.9 & 342 \pm 9 \\ 133^{*} & 39^{*} \\ 25 \pm 9.0 & 235 \pm 16 \\ 57 \pm 2.5 & 313 \pm 7.4 \\ 130^{*} & 33^{*}\end{array}$

that the ribosomal capacity must also have increased (Table 1). Ribosomal involvement in the translation process (i.e. protein synthesis per mg of RNA) was also increased in the dystrophic tissue at 100 and 230 days, but not at 30 days of age. These data possibly suggest that the increase in ribosomal capacity precedes that of a more efficient utilization of ribosomes. Further, at $\mathbf{1 0 0}$ days the large increase of protein synthesis in the afflicted muscle (i.e. $178 \%$; Table 2) may arise out of a greater availability $(78 \%$; Table 1) and a more efficient utilization $(55 \%$; Table 2) of ribosomes. Certainly the more efficient use of existing ribosomes (55\%) is not by itself sufficient to account for the very large increase in synthesis.

Clearly the dystrophic process appears to express itself differently in the hamster than in other species. In contrast with the gross muscle wasting and concomitant losses of non-collagen protein in other species, the afflicted muscles of the hamster are substantially larger (Table 1 and Goldspink, 1976b), and their total protein (see above) and collagen protein (Wrogeman et al., 1971) compositions do not differ from their controls. However, other marked changes in the muscles of the hamster have been reported. These changes include muscle weakness, abnormally shaped nuclei (Homburger et al., 1966), increased synthesis of nucleic acids (Goldspink, $1976 b$ ), structural and biochemical abnormalities of the mitochondria (Wrogeman et al., 1970) and morphological changes of contractile proteins (Homburger et al., 1966). One of the striking features of the morphological changes is the extreme atrophy of some muscle fibres and considerable hypertrophy and regeneration of others (Homburger et al., 1966; Johnson \& Pearse, 1968). To a smaller extent fibre hypertrophy is also a feature associated with other forms of dystrophy (Goldspink \& Rowe, 1968; Ashmore \& Doerr, 1971), including the Duchenne form of the human disorders (Homburger et al., 1966). If the incidence of hypertrophy is greater than that of atrophy in the hamster muscles, this may possibly be a factor explaining the larger sizes of these muscles. A gross infiltration of connective tissue seems unlikely (Johnson \& Pearse, 1968), particularly since there is no disproportionate accumulation of collagenous protein (Wrogeman et al., 1971). Certainly the increased rates of protein synthesis (Table 2) are more consistent with muscle hypertrophy (Hamosh et al., 1967; Goldberg, 1968; Goldspink, 1976c) and regeneration than atrophy, whereas the reverse is true of the increased rates of protein breakdown (Goldberg et al., 1974; Goldspink, $1976 a, c)$. Although increases of protein synthesis have also been reported for the muscles of the dystrophic mouse (Simon et al., 1972; Srivastava, 1968, 1969) and chicken (Weinstock \& Markiewicz, 1974), even greater increases in the degradative rates (Simon et $a l ., 1962)$ favour the net loss of protein from these tissues. The reverse situation appears to exist for the hamster (Table 2). The increased synthetic rates may be caused by several factors, including the elevated activities of certain enzymes involved in the translation process (Srivastava, 1969; Battelle \& Florini, 1973; Weinstock \& Markiewicz, 1974). Another site of control could be at the level of the ribosome. This 
being so, these data (Tables 1 and 2) suggest that there is an increase in both the number of available ribosomes and an increase in the efficiency of their use in translation. Although there appear to be similar increases in both the number (Oppenheimer \& Markiewicz, 1973) and activity (Battelle \& Florini, 1973) of ribosomes in muscles of 2-month-old dystrophic chickens, no such changes were found in the afflicted muscles of the mouse (Watts \& Reid, 1969). The higher concentrations of RNA in the dystrophic muscle (Table 1) are also in keeping with similar findings in other species (Coleman \& Ashworth, 1959; Srivastava, 1968; Polishchuk, 1969), and again correlate with a situation of muscle growth (Hamosh et al., 1967; Goldspink, 1976c).

Although the activities of several muscle proteinases have been found to increase in the hamster (Wrogeman et al., 1971), other experimental animals (Weinstock \& Iodice, 1969) and humans (Pennington \& Robinson, 1968) in association with dystrophy, the exact role of these enzymes in normal protein turnover remains uncertain. Hence it is not clear exactly what the relationship is between the elevated rates of protein breakdown (Table 2) and the increased activities of these intracellular proteinases.

We thank Mr. Paul Anderson, B.Sc., and Miss Patricia Kilpatrick for their skilled assistance in these experiments. This study was supported by the Muscular Dystrophy Group of Great Britain and the Medical Research Council.

\section{References}

Ashmore, C. R. \& Doerr, L. (1971) Exp. Neurol. 30, 431-446

Battelle, B. A. \& Florini, J. R. (1973) Biochemistry 12, 635-643

Coleman, D. L. \& Ashworth, M. E. (1959) Am. J. Physiol. 197, 839-841

Deluca, H. F. \& Cohen, P. P. (1964) in Manometric Techniques (Umbreit, W. W., Burris, R. H. \& Stauffer, J. F., eds.), p. 132, Burgess Publishing Co., Minneapolis

Diehl, J. F. \& Jones, R. R. (1966) Am. J. Physiol. 210, 1080-1085

Fulks, R. M., Li, J. B. \& Goldberg, A. L. (1975) J. Biol. Chem. 250, 290-298

Goldberg, A. L. (1968) J. Cell Biol. 36, 653-658
Goldberg, A. L., Jablecki, C. \& Li, J. B. (1974) Ann. N.Y. Acad. Sci. 228, 190-201

Goldspink, D. F. (1976a) Biochem. J. 156, 71-80

Goldspink, D. F. (1976b) Life Sci. in the press

Goldspink, D. F. (1976c) J. Physiol. (London) in the press

Goldspink, D. F. \& Goldberg, A. L. (1973) Biochim. Biophys. Acta 299, 521-532

Goldspink, G. \& Rowe, R. W. D. (1968) Proc. Symp. Res. Muscular Dystrophy 4th, pp. 116-131, Pitman, London

Hamosh, M., Lesch, M., Baron, J. \& Kaufman, S. (1967) Science 157, 935-937

Homburger, F., Nixon, C. W., Eppenberger, M. \& Baker, J. R. (1966) Ann. N.Y. Acad. Sci. 138, 14-27

Johnson, M. \& Pearse, A. G. E. (1968) Proc. Symp. Res. Muscular Dystrophy 4th, pp. 171-183, Pitman, London

Julian, L. M. \& Asmundson, V. S. (1963) in Muscular Dystrophy in Man and Animals (Bourne, G. H. \& Golarz, M. A., eds.), pp. 458-499, S. Karger, Basel and New York

Lowry, O. H., Rosebrough, N. J., Farr, A. L. \& Randall, R. J. (1951) J. Biol. Chem. 193, 265-275

Manchester, K. L. \& Harris, E. J. (1968) Biochem. J. 108, 177-183

Millward, D. J., Garlick, P. J., James, W. P. T., Nnanyelugo, D. O. \& Ryatt, J. S. (1973) Nature (London) 241, 204-205

Oppenheimer, H. \& Markiewicz, L. (1973) Biochem. Med. 7, 479-490

Pennington, R. J. (1965) in Biochemical Aspects of Neurological Disorders (Cummings, J. N. \& Kremer, M., eds.), pp. 28-50, Blackwell, Oxford

Pennington, R. J. \& Robinson, J. E. (1968) Enzymol. Biol. Clin. 9, 175-179

Polishchuk, S. N. (1969) Ukr. Biokhim. Zh. 41, 611-617

Simon, E. J., Gross, C. S. \& Lessell, I. M. (1962) Arch. Biochem. Biophys. 96, 41-46

Srivastava, U. (1967) Can. J. Biochem. 45, 1419-1429

Srivastava, U. (1968) Can. J. Biochem. 46, 35-41

Srivastava, U. (1969) Arch. Biochem. Biophys. 135, 236-243

Walton, J. N. (1963) in Muscular Dystrophy in Man and Animals (Bourne, G. H. \& Golarz, M. A., eds.), pp. 264-321, S. Karger, Basel and New York

Watts, D. C. \& Reid, J. D. (1969) Biochem. J. 115, 377-382

Weinstock, I. M. \& Iodice, A. A. (1969) in Lysosomes in Biology and Pathology (Dingle, J. T. \& Fell, H. B., eds.), vol. 1, pp. 450-468, Elsevier, Amsterdam

Weinstock, I. M. \& Markiewicz, L. (1974) Biochim. Blophys. Acta 374, 197-206

Wrogeman, K., Blanchaer, M. C. \& Jacobson, B. E. (1970) Life Sct. 9, 1167-1173

Wrogeman, K., Jacobson, B. E. \& Blanchaer, M. C. (1971) Enzyme 12, 322-328 